\title{
Heterogeneous point mutations of the p53 gene in pulmonary fibrosis
}

\author{
S. Hojo*, J. Fujita*, I. Yamadori**, T. Kamei+, T. Yoshinouchi++, Y. Ohtsukił, H. Okada*, \\ S. Bandoh*, Y. Yamaji*, J. Takahara*, T. Fukui\#, M. Kinoshita\#
}

Heterogeneous point mutations of the p53 gene in pulmonary fibrosis. S. Hojo, J. Fujita, I. Yamadori, T. Kamei, T. Yoshinouchi, Y. Ohtsuki, H. Okada, S. Bandoh, Y. Yamaji, J. Takahara, T. Fukui, M. Kinoshita. (CERS Journals Ltd 1998.

ABSTRACT: Lung cancer is a frequent complication in pulmonary fibrosis. Overexpression of 53 proteins has been demonstrated by immunostaining in bronchoepithelial cells in patients with idiopathic pulmonary fibrosis. However, it is still unclear whether this overexpressed 553 protein is wild-type or mutant.

It was hypothesized that pulmonary fibrosis may be a precancerous lesion with deoxyribonucleic acid point mutations in bronchoepithelial cells. Mutations of the p53 gene were tested for by fluorescence-based single-strand conformation polymorphism (FSSCP), cloning-sequencing and immunostaining techniques.

Out of 10 tissue samples that demonstrated overexpression of p53 protein by immunostaining, nine $(90 \%)$ exhibited point mutations and eight $(80 \%)$ exhibited heterogeneous point mutations of the 153 gene. The mutations found in pulmonary fibrosis were scattered throughout the central part of the p53 gene, and both guanine $(G)$ :cytosine $(C)$ to adenine $(A)$ :thymine $(T)$ and $A: T$ to $G: C$ transitions were frequently observed.

In conclusion, frequent heterogeneous point mutations of the $\mathrm{p53}$ gene were detected in pulmonary fibrosis. These mutations may have resulted from several types of deoxyribonucleic acid damage that occurred in bronchoepithelial cells and this may explain previous findings of a very high incidence of lung cancer complicating pulmonary fibrosis.

Eur Respir J 1998; 12: 1404-1408.

Idiopathic pulmonary fibrosis (IPF) is an inflammatory lung disease characterized by the accumulation of inflammatory cells and deposition of collagen resulting in lung remodelling. The prevalence of lung cancer in patients with IPF has been reported to be $31 \%$ [1]. Carcinogenesis is believed to involve multistep genetic mutations and several gene mutations have been found in hyperplastic, metaplastic and dysplastic epithelium [2]. Recently, overexpression of p53 proteins in bronchoepithelial cells has been demonstrated by immunostaining [3]. However, it is still unclear whether this overexpressed p53 protein is wild-type or mutant. It was hypothesized that pulmonary fibrosis may be a precancerous lesion with deoxyribonucleic acid (DNA) point mutations in bronchoepithelial cells. Therefore, mutations of the p53 gene were tested for by fluorescence-based single-strand conformation polymorphism (FSSCP), cloning-sequencing, and immunostaining techniques.

\section{Materials and methods}

\section{Samples and immunohistochemical staining}

Twenty-eight formalin-fixed and paraffin-embedded specimens obtained by open lung biopsy from 28 patients with pulmonary fibrosis were studied. Representative sections, $5 \mu \mathrm{m}$ in thickness, from each case were cut and
*First Dept of Internal Medicine, Kagawa Medical University, Kagawa, Japan. **Second Dept of Pathology, Okayama University Medical School, Japan. +Dept of Internal Medicine, Kagawa Prefectual Central Hospital, Kagawa, Japan. ++Dept of Internal Medicine, Matsuyama Citizen Hospital, Ehime, Japan. ${ }^{*}$ Second Dept of Pathology, Kochi Medical School, Kochi, Japan. \#Otsuka Assay Laboratories, Tokushima, Japan

Correspondence: J. Fujita, First Dept of Internal Medicine, Kagawa Medical University, 1750-1, Miki-cho, Kita-gun, Kagawa, 761-0793, Japan, Fax: 8187891 2147

Keywords: Bronchoepithelial cells, idiopathic pulmonary fibrosis, lung cancer p53, point mutations

Received: January 161998

Accepted after revision July 151998 placed on poly-L-lysine-coated slides (Sigma, St Louis, MO, USA). The specimens were stained with the monoclonal antibody DO7, at 1:30 dilution (Dako, Kyoto, Japan), which recognizes both wild-type and mutant types of p53 protein. For a better immunohistochemical reactivity, dewaxed sections were treated in deionized water (heated at $95 \pm 5^{\circ} \mathrm{C}$ ) in a microwave oven for $5 \mathrm{~min}$. Immunoreaction was carried out using an avidin-biotin peroxidase kit (Histofine SAB-kit; Michirei, Tokyo, Japan). Positive or negative controls in each experiment were run in parallel. The intensity of immunostaining was scored as follows: $+:>50 \%$ positive nuclei in regenerated epithelial cells; \pm : $<50 \%$ of the nuclei of regenerated epithelial cells were positive; and -: none positive. Ten samples from 10 different patients were analysed. Of the 10 patients (five males, five females ranging 44-74 yrs of age (mean 60.2)), six were diagnosed with usual interstitial pneumonia (UIP), three with collagen vascular diseases (two cases of rheumatoid arthritis and one of Sjogren syndrome) and one with nonspecific interstitial pneumonia (NSIP). Lung tissues obtained from patients with collagen vascular diseases exhibited a UIP pattern on pathological examination.

Polymerase chain reaction and fluorescence-based single-strand conformation analysis

Since the hot spots for p53 mutations are in exons 5-8 in lung cancers $(90 \%)$, we tested for mutations in exons 5- 
8 of the p53 gene by polymerase chain reaction (PCR)FSSCP [4], a more sensitive method for the detection of gene mutations than PCR-single-strand conformation polymorphism. Ten tissue specimens (six stained + and four \pm ) were dewaxed with xylene, rinsed in ethanol and vacuum desiccated. DNA was extracted from crude tissue samples by boiling. Oligonucleotide primers were used to amplify each exon from exons 5 to 8 (for exon 5: 5'-TTC CTC TTC CTG CAG TAC TC-3' and 5'-GCC CCA GCT GCT CAC CAT CG-3'; for exon 6: 5'-CAC TGA TTG CTC TTA GGT CTG-3' and 5'-AGT TGC AAA CCA GAC CTC AG-3'; for exon 7: 5'-GAG GCA AGC AGA GGC TGG-3' and 5'-CCA AGG CGC ACT GGC CTC-3'; and for exon 8: 5'-CCT ATC CTG AGT AGT GGT AAT C-3' and 5'-GTC CTG CTT GCT TAC CTC GC-3') which were labelled at their 5 ' ends with fluorescein derivatives by the Fluorprime method (Pharmacia, Uppsala, Sweden). The PCR conditions were as follows: total volume $50 \mu \mathrm{L}$, containing $1 \mu \mathrm{M}$ each primer, $10 \mu \mathrm{M}$ deoxyadenosine triphosphate (dATP), deoxycytodine triphosphate (dCTP), deoxyguanosine triphosphate (dGTP) and deoxythymidine triphosphate (dTTP), $100 \mathrm{ng}$ of genomic DNA and 0.125 $\mathrm{U}$ of Taq polymerase. All PCRs were preformed in a Robo Cycler 40 (Stratagene, La Jolla, CA, USA). Firstly, there was one cycle of denaturation at $95^{\circ} \mathrm{C}$ for $2 \mathrm{~min}$, annealing at $56^{\circ} \mathrm{C}$ for $3 \mathrm{~min}$ and extension at $72^{\circ} \mathrm{C}$ for $2 \mathrm{~min}$. Secondly, there were 39 cycles of denaturation at $95^{\circ} \mathrm{C}$ for $1 \mathrm{~min}$, annealing at $56^{\circ} \mathrm{C}$ for $1.5 \mathrm{~min}$, extension at $72^{\circ} \mathrm{C}$ for $1.5 \mathrm{~min}$ and finally maintaining a last extension step for $10 \mathrm{~min}$. After amplification, the reaction mixture for each exon was mixed with $100 \%$ formamide containing 5 $\mathrm{mg} \cdot \mathrm{mL}^{-1}$ dextran blue 2000 (Pharmacia). The mixtures were heated at $95^{\circ} \mathrm{C}$ for $3 \mathrm{~min}$ and immediately placed on ice for $5 \mathrm{~min}$. Then, $2 \mu \mathrm{L}$ of the mixture was deposited on a $5 \%$ glycerol $/ 7 \%$ polyacrylamide gel. Electrophoresis was performed using an ALF 2 automated DNA sequencer (Pharmacia) at $45 \mathrm{~W}$ for $240 \mathrm{~min}$.

Cloning of polymerase chain reaction products, PCRFSSCP of recombinant clones and sequencing of recombinant clones

For samples with abnormal profiles of fluorescent amplicons on FSSCP analysis, a new PCR was performed as described above using nonlabelled primers (each primer pair for exons 6, 7 and 8). The resulting amplicons were cloned in the TA cloning site of the pCR2 cloning vector (Invitrogen Carlsbad, CA, USA) using T4 DNA ligase (TaKaRa, Tokyo, Japan). Fifty recombinant colonies were further selected and cultured in LB medium. For identification of mutant colonies, the DNA was PCR amplified using labelled primers (each primer pairs of exon 6,7 and 8) and the PCR products were then analysed by FSSCP. For these colonies, when FSSCP analysis revealed abnormal profiles, sequence analysis was also performed using an ALF 2 DNA sequencer with a M13 (-40) fluorescent primer.

\section{Results}

Examples of the results of positive immunostaining with DO7 are shown in figure 1 . Overexpression of the

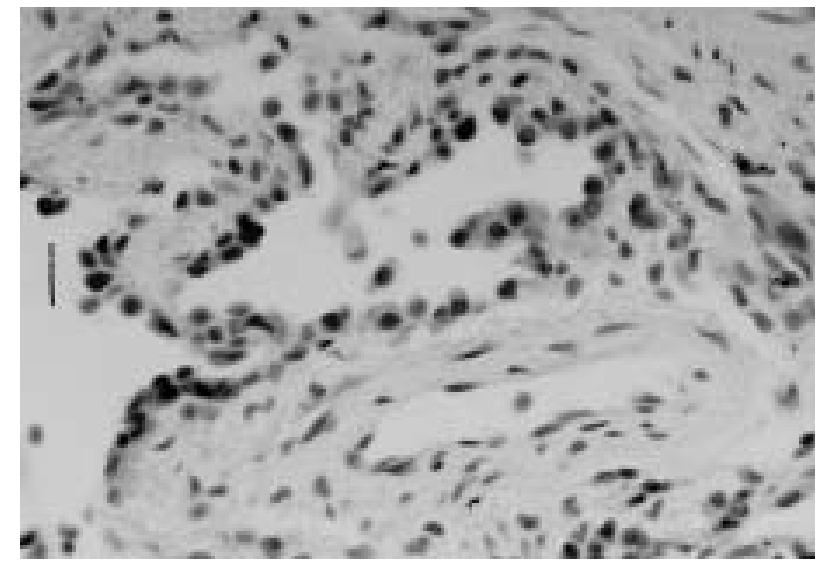

Fig. 1. - Example of positive staining (+) with anti-p53 antibody (DO7) by immunohistochemistry in interstitial pneumonia. (Internal scale bar $=20 \mu \mathrm{m}$.)

p53 protein in the nuclei of the regenerated alveolar epithelium was observed (this case was considered as + ).

To detect the p53 gene mutation in the 10 samples selected (six stained + and four stained \pm ), an attempt was made to extract genomic DNA. However, for exon 5, the PCR was unsuccessful for eight out of the 10 tissue samples. Thus, the FSSCP analysis was performed in the other 32 exons.

The results of PCR-FSSCP analysis are given in table 1. In 10 cases, PCR-FSSCP analysis revealed no abnormality for exon 5 . There were two cases of abnormal peaks $(20 \%)$ for exon 6, 10 cases $(100 \%)$ for exon 7 and three cases $(30 \%)$ for exon 8 . An example of the results of PCR-FSSCP analysis is shown in figure 2 . Therefore, the cloning and sequencing of these 15 samples were performed. To screen for p53 gene mutations, FSSCP analysis was performed on a total of 750 clones from the above 15 samples. Of the 750 clones, 130 exhibited abnormal fluorescent peaks. An example of the results of PCRFSSCP analysis is shown in figure 3 . Sequence analysis was performed for these 130 clones.

The cloning and subsequent sequencing results are given in table 2 . Out of the 10 patients evaluated, nine (90\%) exhibited p53 gene mutations, and eight (80\%) exhibited heterogeneous point mutations in the same samples. Guanine $(\mathrm{G})$ :cytosine $(\mathrm{C})$ to adenine $(\mathrm{A})$ :thymine $(\mathrm{T}) \mathrm{mu}-$ tations were detected in 15 samples $(51.7 \%), \mathrm{A}: \mathrm{T}$ to $\mathrm{G}: \mathrm{C}$ in 12 samples $(41.3 \%), \mathrm{G}: \mathrm{C}$ to $\mathrm{C}: \mathrm{G}$ in one sample $(3.4 \%)$ and A:T to T:A in one sample (3.4\%).

\section{Discussion}

In this study, immunostaining with anti-p53 protein antibody was performed and accumulation of the $\mathrm{p} 53$ protein in neoformative epithelial cells in pulmonary fibrosis demonstrated. In addition, using PCR-FSSCP, cloning and sequence analysis, heterogeneous point mutations of the p53 gene were detected in lung tissue samples ob-tained from patients with interstitial fibrosis.

The p53 gene encodes a nuclear protein that binds to and modulates the expression of genes that play an important role in DNA repair, cell division, and cell death by apoptosis [5]. The relationship of p53 mutation with tumour progression has been examined for many tumours 
Table 1. - Results of polymerase chain reaction-fluorescence-based single-strand conformation polymorphism in archival open lung biopsies

\begin{tabular}{|c|c|c|c|c|c|c|c|c|c|}
\hline \multirow{2}{*}{$\begin{array}{l}\text { Patient } \\
\text { No. }\end{array}$} & \multirow{2}{*}{$\begin{array}{l}\text { Age } \\
\text { yrs }\end{array}$} & \multirow[t]{2}{*}{ Sex } & \multirow[t]{2}{*}{ Diagnosis } & \multirow[t]{2}{*}{ Smoking } & \multirow[t]{2}{*}{ p53 Immunostaining } & \multicolumn{4}{|c|}{ Exon } \\
\hline & & & & & & 5 & 6 & 7 & 8 \\
\hline 1 & 57 & $\mathrm{~F}$ & RA lung & No & + & NA & $\mathrm{N}$ & A & A \\
\hline 2 & 67 & $\mathrm{~F}$ & IPF & No & \pm & NA & $\mathrm{N}$ & A & $\mathrm{N}$ \\
\hline 3 & 44 & M & IPF & Yes & \pm & NA & $\mathrm{N}$ & $\mathrm{A}$ & $\mathrm{N}$ \\
\hline 4 & 51 & $\mathrm{~F}$ & IPF & No & + & NA & $\mathrm{N}$ & A & $\mathrm{N}$ \\
\hline 5 & 70 & M & RA lung & No & \pm & $\mathrm{N}$ & $\mathrm{N}$ & A & $\mathrm{N}$ \\
\hline 6 & 74 & $\mathrm{M}$ & IPF & Yes & \pm & $\mathrm{N}$ & $\mathrm{N}$ & A & $\mathrm{N}$ \\
\hline 7 & 66 & M & NSIP & Yes & + & NA & $\mathrm{N}$ & A & $\mathrm{N}$ \\
\hline 8 & 47 & $\mathrm{~F}$ & IPF & No & + & NA & A & A & A \\
\hline 9 & 67 & M & IPF & Yes & + & NA & $\mathrm{N}$ & A & $\mathrm{N}$ \\
\hline 10 & 59 & $\mathrm{~F}$ & Sjogren & No & \pm & NA & A & A & $\mathrm{A}$ \\
\hline
\end{tabular}

F: female; M: male; RA: rheumatoid arthritis; IPF: idiopathic pulmonary fibrosis; NSIP: nonspecific interstitial pneumonia; Sjogren: Sjogren syndrome; NA: not amplified; N: normal; A: abnormal; +: >50\% positive; \pm : ð50\% positive; -: none positive.

advanced disease has been found for many tumour types $[6,7]$. However, recent studies have indicated that p53 alteration may occur as an early event in premalignant lesions [2]. In a survey of archival material from radonassociated lung cancer patients, VAHAKANGAS et al. [8] reported immunocytochemical and molecular evidence of p53 mutations in preinvasive, microinvasive and invasive lesions of one patient. In addition, Sozzi et al. [9] reported the deletion of $17 \mathrm{p}$ and $\mathrm{p} 53$ mutations in preneoplastic lesions of the lung and suggested that these changes may take place early in the process of lung carcinogenesis. Furthermore, p53 abnormalities, gene alteration and protein accumulation are frequently found in dysplastic lesions surrounding or adjacent to squamous cell carcinomas of the bronchus [2]. Detection of these alterations in surrounding normal, hyperplastic, metaplastic or dysplastic
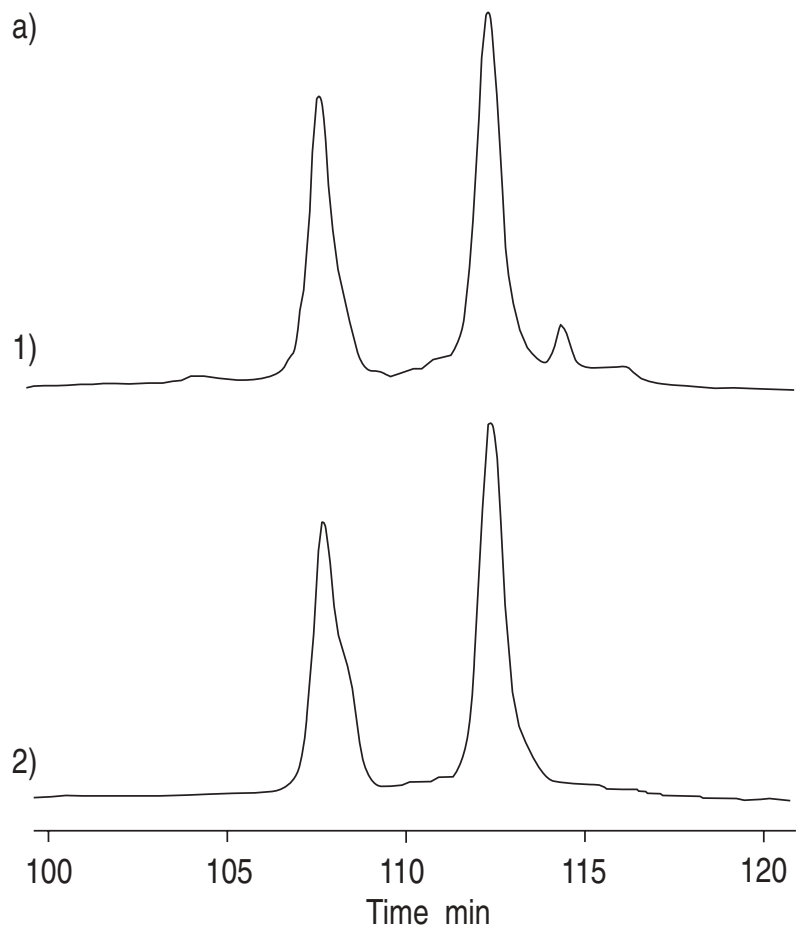

epithelium would further extend the timing of alteration to the pretransformation period [2].

It has been reported that pulmonary fibrosis is associated with lung cancer and that the prevalence of lung cancer in patients with IPF is $31 \%$ [1]. It has also been reported that synchronous multiple lung cancer is associated with pulmonary fibrosis [10]. Since cancer is the result of an accumulation of genetic changes, and one of the most important genetic lesions in the p53 gene is base substitution, it is possible that p53 gene point mutations occur in regenerated metaplastic or dysplastic epithelial cells in pulmonary fibrosis.

In this study, the detection of heterogeneous point mutations of the p53 gene in patients with pulmonary fibrosis was surprising. However, NeEs et al. [11] reported similar point mutations of the p53 gene in tumour-distant epithelia of head and neck cancer patients and concluded that

b)

1)
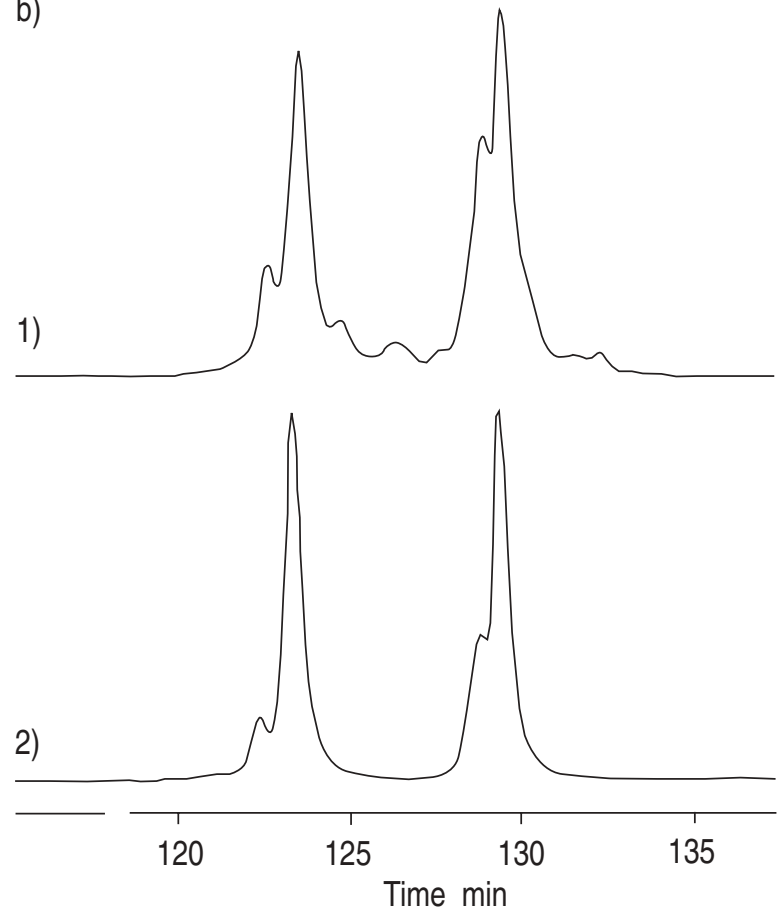

Fig. 2. - a) Examples of a peak profile of fluorescent amplicons for exon 7 of the p53 gene by polymerase chain reaction-fluorescence-based singlestrand conformation polymorphism (PCR-FSSCP) analysis: 1) lung specimen obtained from a patient (No. 9); and 2) peripheral lymphocytes from a normal volunteer. b) Examples of a peak profile of fluorescent amplicons for exon 8 of the p53 gene by PCR-FSSCP analysis: 1) lung specimen obtained from a patient (No. 10); and 2) peripheral lymphocytes from a normal volunteer. 


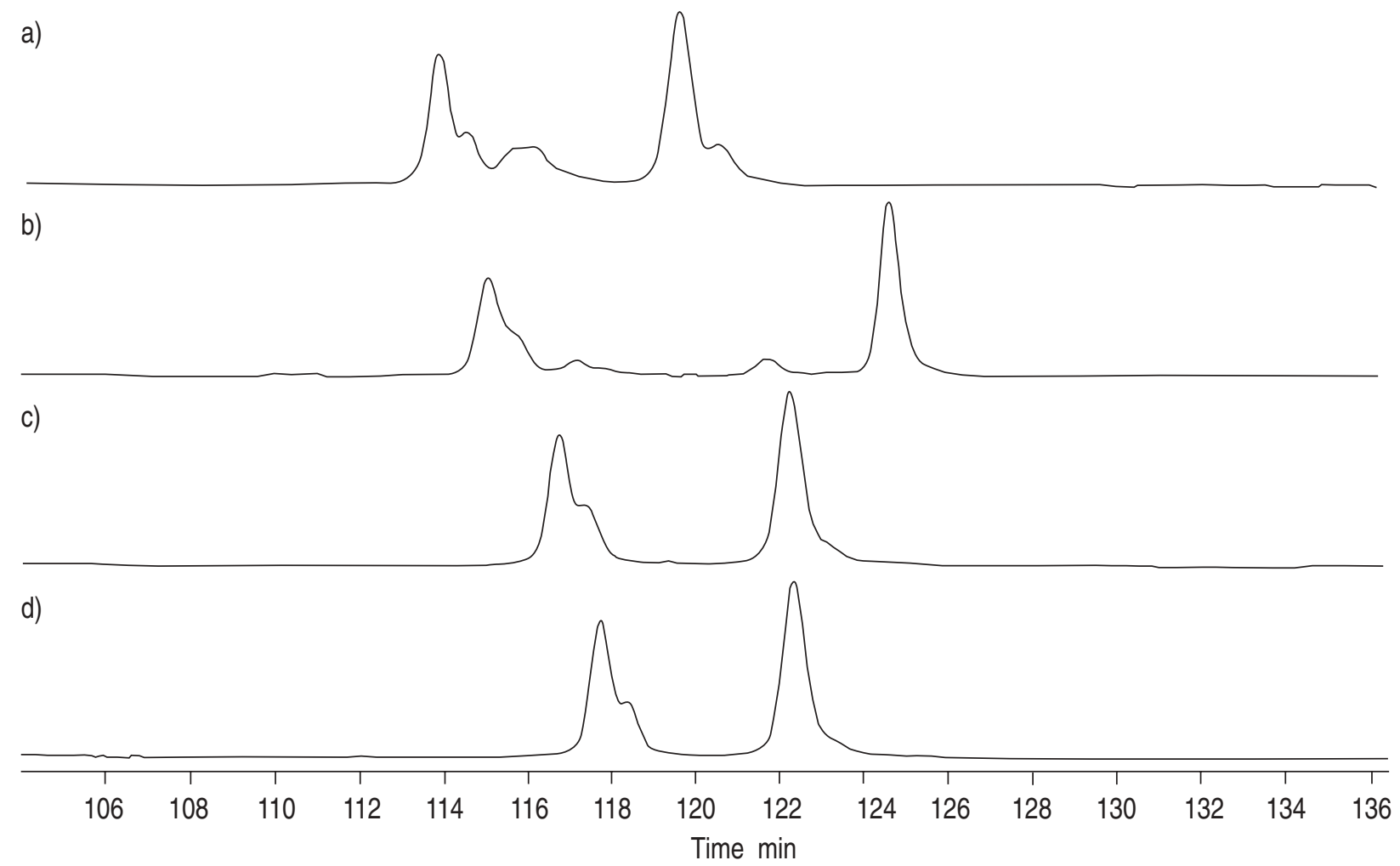

Fig. 3. - Examples of a peak profile of fluorescent amplicons of the p53 gene after cloning by polymerase chain reaction-fluorescence-based singlestrand conformation polymorphism (PCR-FSSCP) analysis: a-c) abnormal clones derived from exon 7 of the p53 gene obtained from a patient (No. 6); d) peripheral lymphocytes from a normal volunteer.

the mutation of the p53 gene is an early event in head and neck carcinogenesis, preceding signs of overt neoplasia, and that different p53 mutations in multiple foci may be the molecular basis for the development of multiple tumours.

The relationship between the point mutations of the p53 gene and clinical findings was also considered. Interestingly, in a patient who had a point mutation (the same as reported for lung cancer (codon 248 CGG to CAG transition)) lung cancer developed several years after the open lung biopsy (the lung cancer specimen could not be examined for p53 mutation). Since there was no lung cancer in the lung specimen obtained by open lung biopsy, it is likely that the point mutations of the p53 gene found in the pulmonary fibrosis sample could be related to the development of lung cancer. Although pulmonary fibrosis had progressed, no lung cancer was detected in the remaining nine patients. In addition, although all nine patients with the pathological diagnosis of UIP demonstrated point mutations of the p53 gene, the one patient diagnosed with NSIP exhibited no such mutation, suggesting that a close relationship exists between UIP and p53 point mutations.

SSCP analysis is a very sensitive method for the detection of point mutations (80\%) and is routinely used [12]. SSCP is useful in screening tumour samples with mixed cell populations containing both mutant and wild-type p53 alleles, even when the background of the wild-type p53 alleles forms as much as $85-95 \%$ of the total population of amplified alleles [13]. However, since the lung specimens obtained from patients with pulmonary fibrosis by open lung biopsy consisted of heterogeneous cells (e.g. epithelial cells, mesenchymal cells, and inflamma- tory cells), SCCP analysis had limited sensitivity in detecting point mutation of the p53 gene in pulmonary fibrosis. To overcome this problem, immunostaining of p53 protein was used and then PCR-FSSCP (which is more sensitive than PCR-SSCP [4]), followed by cloning and sequence analysis of abnormal DNA to demonstrate point mutations of the p53 gene.

The possibility of false-positive results should be discussed. Since PCR-FSSCP analysis, cloning and sequencing were used, PCR errors as well as sequence errors should be considered. Tindall and Kunkel [14] reported that the Taq polymerase produces single-base substitution errors at a ratio ranging from $1: 7,000$ to $1: 11,700$ nucleotides polymerized, with $\mathrm{T}$ to $\mathrm{C}$ transition being the predominant change. However, in the present study, G to A, A to $\mathrm{G}$ and $\mathrm{C}$ to $\mathrm{T}$ transitions were more frequently observed. Therefore, the possibility that PCR error occurred in this study appears to be low. To exclude sequence errors, a restriction fragment length polymorphism (RFLP) analysis was also performed using the same samples. RFLP analysis yielded positive results demonstrating point mutations in the samples prior to sequencing (data not shown). Therefore, the possibility that sequence errors occurred appears to be negligible.

The possibility of point mutations of the p53 gene in cells other than bronchoepithelial cells should be considered. Since the mutant p53 protein has a relatively long half-life and accumulates in the nucleoli, it is possible to detect it by immunohistochemical techniques. Since we and other investigators have demonstrated overexpression of the p53 protein only in regenerated bronchoepithelial cells [3], it was assumed that point mutations of the p53 
Table 2. - Results of sequencing of exons 6, 7 and 8

\begin{tabular}{|c|c|c|c|}
\hline $\begin{array}{l}\text { Patient } \\
\text { No. }\end{array}$ & $\begin{array}{c}\text { Number of } \\
\text { codon* }\end{array}$ & $\begin{array}{l}\text { Mutations } \\
\text { detected }\end{array}$ & $\begin{array}{l}\text { Changes in } \\
\text { amino acids }\end{array}$ \\
\hline \multirow[t]{2}{*}{1} & 261 & $\mathrm{AG} \rightarrow \mathrm{CG}$ & - \\
\hline & 287 & $\mathrm{GAG} \rightarrow \mathrm{GAA}$ & Glu $\rightarrow$ Glu \\
\hline \multirow[t]{3}{*}{2} & 248 & $\mathrm{CGG} \rightarrow \mathrm{TGG}$ & Arg $\rightarrow$ Trp \\
\hline & 257 & $\mathrm{CTG} \rightarrow \mathrm{CTA}$ & Leu $\rightarrow$ Leu \\
\hline & 259 & $\mathrm{GAC} \rightarrow \mathrm{CCG}$ & Asp $\rightarrow$ Gly \\
\hline \multirow[t]{3}{*}{3} & 245 & $\mathrm{GGC} \rightarrow \mathrm{AGC}$ & Gly $\rightarrow$ Ser \\
\hline & 248 & $\mathrm{CGG} \rightarrow \mathrm{GGG}$ & Arg $\rightarrow$ Gly \\
\hline & 249 & $\mathrm{AGG} \rightarrow \mathrm{GGG}$ & Arg $\rightarrow$ Gly \\
\hline 4 & 255 & $\mathrm{ATC} \rightarrow \mathrm{ATT}$ & $\mathrm{Ile} \rightarrow \mathrm{Ile}$ \\
\hline \multirow[t]{2}{*}{5} & 229 & $\mathrm{TGT} \rightarrow \mathrm{CGT}$ & Cys $\rightarrow$ Arg \\
\hline & 244 & $\mathrm{GGC} \rightarrow \mathrm{GAC}$ & Asp $\rightarrow$ Asp \\
\hline \multirow[t]{3}{*}{6} & 225 & $\mathrm{GTT} \rightarrow \mathrm{GCT}$ & Val $\rightarrow$ Ala \\
\hline & 248 & $\mathrm{CGG} \rightarrow \mathrm{CAG}$ & $\mathrm{Arg} \rightarrow \mathrm{Gln}$ \\
\hline & 254 & $\mathrm{ATC} \rightarrow \mathrm{ACC}$ & $\mathrm{Ile} \rightarrow \mathrm{Thr}$ \\
\hline 7 & - & - & - \\
\hline \multirow[t]{5}{*}{8} & 197 & $\mathrm{GTG} \rightarrow \mathrm{GAG}$ & $\mathrm{Val} \rightarrow \mathrm{Glu}$ \\
\hline & 213 & $\mathrm{CGA} \rightarrow \mathrm{CGG}$ & $\mathrm{Arg} \rightarrow \mathrm{Arg}$ \\
\hline & 255 & $\mathrm{ATC} \rightarrow \mathrm{ATT}$ & $\mathrm{Ile} \rightarrow \mathrm{Ile}$ \\
\hline & 277 & $\mathrm{TGT} \rightarrow \mathrm{TGC}$ & Cys $\rightarrow$ Cys \\
\hline & 302 & $\mathrm{GGG} \rightarrow \mathrm{GAG}$ & Gly $\rightarrow$ Glu \\
\hline \multirow[t]{5}{*}{9} & 231 & $\mathrm{ACC} \rightarrow \mathrm{ACT}$ & $\mathrm{Thr} \rightarrow \mathrm{Thr}$ \\
\hline & 246 & $\mathrm{ATG} \rightarrow \mathrm{ATA}$ & Met $\rightarrow$ Ile \\
\hline & 247 & $\mathrm{AAC} \rightarrow \mathrm{GAC}$ & Asn $\rightarrow$ Asp \\
\hline & 260 & $\mathrm{TCC} \rightarrow \mathrm{TTC}$ & Ser $\rightarrow$ Phe \\
\hline & 260 & $\mathrm{TCC} \rightarrow \mathrm{TTC}$ & Ser $\rightarrow$ Phe \\
\hline \multirow[t]{5}{*}{10} & 218 & $\mathrm{GTG} \rightarrow \mathrm{GCG}$ & $\mathrm{Val} \rightarrow \mathrm{Ala}$ \\
\hline & 220 & $\mathrm{TAT} \rightarrow \mathrm{CAT}$ & $\mathrm{Tyr} \rightarrow \mathrm{His}$ \\
\hline & 221 & $\mathrm{GAG} \rightarrow \mathrm{AAG}$ & Glu $\rightarrow$ Lys \\
\hline & 246 & $\mathrm{ATG} \rightarrow \mathrm{ATA}$ & Met $\rightarrow$ Ile \\
\hline & 270 & $\mathrm{TTT} \rightarrow \mathrm{TTC}$ & $\mathrm{Phe} \rightarrow \mathrm{Phe}$ \\
\hline
\end{tabular}

*: codons and frequencies of the point mutations are summarized below: exon 6 : 197, $1 ; 213,1 ; 218,1 ; 220,1 ; 221,1$; exon $7: 225,1 ; 229,1 ; 231,1 ; 244,1 ; 245,1 ; 246,2 ; 247,1 ; 248,3$; 249,$1 ; 254,1 ; 255,2 ; 257,1 ; 259,1 ; 260,2 ; 261,1$; exon 8 : 270,$1 ; 277,1 ; 287,1 ; 302,1$. Frequencies of the types of mutation are summarized below: $\mathrm{G} \rightarrow \mathrm{A}, 9 ; \mathrm{T} \rightarrow \mathrm{C}, 7 ; \mathrm{C} \rightarrow \mathrm{T}, 6$; $\mathrm{A} \rightarrow \mathrm{G}, 5 ; \mathrm{C} \rightarrow \mathrm{G}, 1 ; \mathrm{T} \rightarrow \mathrm{A}, 1$. (Standard amino acid and nucleotide designations used.)

gene did not occur in other mixed cells. However, we are planning to use an in situ PCR method in the near future to confirm this.

The possibility of false-negative results should also be considered. Since immunohistochemistry was used to screen the samples to evaluate the p53 mutation, other p53 mutations that are not expressed as p53 accumulation could not be detected. In addition, only hot spots for the p53 mutations (exons 5, 6, 7 and 8) were evaluated; mutations in other exons were not evaluated. Therefore, the study may have underestimated the frequency of the p53 mutations.

Although p53 plays a crucial role in the molecular pathogenesis of lung cancer, it is not the only event and, consequently, the documentation of higher rates of p53 mutation does not justify completely the high rate of the occurrence of lung cancer. For example, deletion of the short arm of chromosomes 3 and 17 is thought to precede the p53 mutation in hyperproliferative epithelium $[9,15]$. Therefore, future studies are required to evaluate other genetic abnormalities in IPF. In addition, it is necessary to investigate the pattern of mutations in lung cancers arising in patients with pulmonary fibrosis, comparing the mutations in neoplastic and non-neoplastic tissues.

In summary, frequent heterogeneous point mutations of the p53 gene were detected in pulmonary fibrosis. These mutations may have resulted from several types of deoxyribonucleic acid damage that occurred in bronchoepithelial cells and this may explain the previous findings of a very high incidence of lung cancer-complicating pulmonary fibrosis.

\section{References}

1. Nagai A, Chiyotani A, Nakadate T, Konno K. Lung cancer in patients with idiopathic pulmonary fibrosis. Tohoku J Exp Med 1992; 167: 231-237.

2. Furihata M, Sonobe H, Ohtsuki Y. The aberrant p53 protein (Review). Int J Oncol 1995; 6: 1209-1226.

3. Kuwano K, Kunitake R, Kawasaki M, et al. p21 Wafl/Cip// Sdil and p53 expression in association with DNA strand breaks in idiopathic pulmonary fibrosis. Am J Respir Crit Care Med 1996; 154: 477-483.

4. Katsuragi K, Chiba W, Matsubara Y, Ikeda S, Ueta C, Kinoshita M. A sensitive and high-resolution method for the detection of mutations in the p53 gene using fluorescence-based PCR-SSCP. Biomed Res 1995; 16: 273-279.

5. Carson DA, Lois A. Cancer progression and p53. Lancet 1995; 346: 1009-1011.

6. Hollstein M, Sidransky D, Vogelstein B, Harris CC. p53 mutations in human cancers. Science 1991; 253: 49-53.

7. Harris CC, Hollstein M. Clinical implications of the p53 tumor suppressor gene. N Engl J Med 1993; 329: 1318 1327.

8. Vahakangas KH, Samet JM, Metcalf RA, et al. Mutations of p53 and ras genes in radon-associated lung cancer from uranium miners. Lancet 1992; 339: 576-580.

9. Sozzi G, Miozzo M, Donghi R, et al. Deletions of $17 \mathrm{p}$ and p53 mutations in preneoplastic lesions of the lung. Cancer Res 1992; 52: 6079-6082.

10. Mizushima Y, Kobayashi M. Clinical characteristics of synchronous multiple lung cancer associated with idiopathic pulmonary fibrosis. A review of Japanese cases. Chest 1995; 108: 1272-1277.

11. Nees M, Homann N, Discher H, et al. Expression of mutated p53 occurs in tumor-distant epithelia of head and neck cancer patients: a possible molecular basis for the development of multiple tumors. Cancer Res 1993; 53: 4189-4196.

12. Orita M, Suzuki Y, Sekiya T, Hayashi K. Rapid and sensitive detection of point mutations and DNA polymorphisms using the polymerase chain reaction. Genomics 1989; 5: 874-879.

13. Wu JK, Ye Z, Darras BT. Sensitivity of single-strand conformation polymorphism (SSCP) analysis in detecting p53 point mutations in tumors with mixed cell populations. Am J Hum Genet 1993; 52: 1273-1275.

14. Tindall KR, Kunkel TA. Fidelity of DNA synthesis by the Thermus aquaticus DNA polymerase. Biochemistry 1988; 27: 6008-6013.

15. Sundaresan V, Ganly P, Hasleton P, et al. p53 and chromosome 3 abnormalities, characteristic of malignant lung tumours, are detectable in preinvasive lesions of the bronchus. Oncogene 1992; 7: 1989-1997. 